\title{
CHANGES IN proHB-EGF EXPRESSION AFTER FUNCTIONAL ACTIVATION OF THE IMMUNE SYSTEM CELLS
}

\author{
T. O. CHUDINA ${ }^{1,2}$, A. J. LABINTSEV ${ }^{1}$, S. I. ROMANIUK ${ }^{1}$, \\ D. V. KOLYBO ${ }^{1,2}$, S. V. KOMISARENKO ${ }^{1}$ \\ ${ }^{1}$ Palladin Institute of Biochemistry, National Academy \\ of Sciences of Ukraine, Kyiv; \\ ${ }^{2}$ ESC Institute of Biology and Medicine, \\ Taras Shevchenko National University of Kyiv, Ukraine; \\ e-mail: kolibo@biochem.kiev.ua
}

The level of proHB-EGF expression on J774, Raji, KG-1 cells derived from different types of human and mouse immune system cells under the standard in vitro culture conditions and during functional activation of these cells was investigated. Changes in the proHB-EGF expression on the cell surface were found to depend on the density of cell population, the content of fetal bovine serum in the culture medium, the presence of mitogenic factors - bacterial lipopolysaccharide and recombinant soluble HB-EGF - rsHB-EGF, as well as anti-mitogenic factor - diphtheria toxoid (CRM197). The results obtained are important for the understanding of the functional role of proHB-EGF receptor on the surface of macrophage-like cells and B lymphocytes and indicate the involvement of this receptor in immune response regulation in organism.

Key word s: proHB-EGF, expression, cell lines, macrophages, B lymphocytes, lipopolysaccharide (LPS), recombinant proteins, sHB-EGF, inactive diphtheria toxin CRM197.

$\mathrm{H}$ eparin-binding epidermal growth factor (EGF)-like growth factor (HB-EGF) is expressed on the cell surface as a 208 amino acid transmembrane protein - proHB-EGF, which consists of propeptide and 5 domains: heparin-binding, EGF-like, juxtamembrane, transmembrane and cytoplasmic domains [1]. Processing of proHB-EGF by matrix metalloproteinases (MMPs) and a disintegrin and metalloproteinases (ADAMs) results in the formation of 87 amino acid soluble form of HBEGF (sHB-EGF) which contains heparin-binding and EGF-like domains [2].

sHB-EGF, owing to the EGF-like domain, activates two types of tyrosine kinases receptors - human epidermal growth factor receptors HER1 and HER4 [3, 4]. sHB-EGF is a potent stimulator of cell proliferation and migration, however, its main targets are fibroblasts, smooth muscle cells and epithelial cells [5].

proHB-EGF induces proliferation and helps the cell to adhere; it forms complexes with other membrane proteins (such as CD9, DRAP27 (mon- key homologue of (D9), integrin $\alpha 3 \beta 1$ ) essential for cell adhesion and cell migration; and it is involved in signal transmission between cells [6]. In addition to stimulating the cell proliferation and migration, proHB-EGF was shown to be implicated in a variety of normal physiological processes, such as pregnancy, wound healing, neuronal recovery after hypoxia and ischemia; as well as in pathological processes, such as tumor growth, smooth muscle cell hyperplasia and atherosclerosis [7].

Furthermore, proHB-EGF is a receptor for diphtheria toxin (DT), the main pathogenic factor of Corynebacterium diphtheriae, the pathogenic bacterium that causes diphtheria [8]. A toxin can penetrate via an alternative pathway only into immune system cells (macrophages and toxin-specific B cells), owing to phagocytosis and DT-specific immunoglobulin receptors [9]. DT receptor-binding subunit B (SubB) interacts with the EGF-like domain of proHB-EGF allowing the enzymatically active subunit A (SubA) of DT to penetrate the cell. SubA ADP-ribosylates eukaryotic translation elongation factor 2 (eEF2) that

(C) 2017 Chudina T. O. et al. This is an open-access article distributed under the terms of the Creative Commons Attribution License, which permits unrestricted use, distribution, and reproduction in any medium, provided the original author and source are credited. 
leads to inhibition of protein synthesis and cell death [10]. Cells of different species vary in susceptibility to DT. Thus, cells of most mammalian species (including human and guinea pig) are susceptible to DT, while mouse and rat cells are highly resistant [11].

ProHB-EGF is expressed in the cells of many organs and tissues including vascular endothelial cells, smooth and skeletal muscle cells, keratinocytes, neurons and tumor cells [12]. ProHB-EGF is also expressed on the immune system cells: macrophages [5], CD4+ T cells [13] and B cells [14] that perform totally different functions. The specific features of proHB-EGF expression on various types of immune system cells and its role in the immune processes remain unexplored. The study of immune cell receptors and their signal transduction pathways is an important area of research, given the prospect of using these fundamental data to develop mechanisms to control immune response, as well as to develop drugs for the treatment of immunodeficiency, autoimmune diseases, cancer, transplantation complications, etc.

The aim of this work was to study changes in proHB-EGF expression on the cell lines derived from macrophage-like cells and B lymphocytes under the influence of various activating factors such as: changes in cell density in culture, changes in the content of fetal bovine serum (FBS) in the culture medium, the presence of mitogenic factor - bacterial lipopolysaccharide (LPS), as well as previously obtained recombinant proteins: nontoxic form of diphtheria toxin - CRM197 [15] or soluble form of HB-EGF - rsHB-EGF [16].

Previously, we suggested determining proHBEGF expression on the cell surface using recombinant fluorescent DT derivatives, in particular, SubB genetically fused to enhanced green fluorescent protein (EGFP) - EGFP-SubB [17]. This approach allowed determining proHB-EGF expression on the cells not only of susceptible to DT animal species but also resistant to DT [18]. To study the proHBEGF expression at functional activation of various types of the immune system cells we used the abovementioned approach with EGFP-SubB-labeled cells and measuring their fluorescence by flow cytometry.

\section{Materials and Methods}

J774, Raji and KG-1 cell lines derived from human and mouse B cells and macrophage-like cells were used in our work. The J774 cell line was obtained from mouse sarcoma cells (mouse macrophage-like cells), the Raji cell line originated from cells of the Burkitt's lymphoma of the 11-year-old boy (human B cells), and the KG-1 cell line - from bone marrow cells of the 59-year-old patient with acute myelogenous leukemia (human macrophagelike cells). The cell cultures were obtained from the bank of cell lines of RE Kavetsky Institute of Experimental Pathology, Oncology and Radiobiology, National Academy of Sciences of Ukraine.

In the research we also used previously obtained in our laboratory recombinant proteins: nontoxic DT analogue - CRM197 [15], HB-EGF soluble form - rsHB-EGF [16] and genetically fused protein EGFP-SubB that consists of subunit B of DT and enhanced green fluorescent protein (EGFP) [17]. CRM197 differs from DT by substitution of Gly52 for Glu within the enzymatically active subunit A that results in a complete loss of toxicity, and slightly alters the conformation of the receptor-binding subunit B. Expression and isolation of recombinant proteins were performed according to the protocols and recommendations described in the mentioned above publications.

Cell culture. Cells were grown to 70-90\% confluency in DMEM culture medium containing 10\% FBS, streptomycin (100 mg/l), penicillin (10 $000 \mathrm{U})$, and amphotericin $\mathrm{B}(250 \mu \mathrm{g} / \mathrm{l})$ at $37{ }^{\circ} \mathrm{C}, 5 \% \mathrm{CO}_{2}$ concentration.

To study the effect of changing cell density in culture on the proHB-EGF expression, the cells were plated into 24 -well plates in a number of $0.75 \times 10^{5}$, $1.5 \times 10^{5}$, or $3 \times 10^{5}$ cells per well, and incubated under identical conditions.

To study the effect of changes in the medium FBS content on proHB-EGF expression, the cells were plated into 24 -well plates of $1.5 \times 10^{5}$ cells per well in DMEM medium containing 2, 10 , or $20 \%$ FBS.

To study the LPS impact on proHB-EGF expression, the cells were plated into 24-well plates in a number of $1.5 \times 10^{5}$ cells per well in DMEM medium containing 10\% FBS. After 6 h of adaptation, a mitogenic bacterial factor LPS (Sigma, USA) was added to a final concentration of $1 \mu \mathrm{g} / \mathrm{ml}$, and the cells were incubated for $16 \mathrm{~h}$.

To study the influence of the recombinant proteins: nontoxic DT analogue - CRM197 or rsHBEGF on the proHB-EGF expression, the cells were plated into 24-well plates in a number of $1.5 \times 10^{5}$ cells per well in DMEM culture medium containing 
$10 \%$ FBS. After $6 \mathrm{~h}$ of adaptation, CRM197 to a final concentration of $1.5 \mu \mathrm{M}$ or rsHB-EGF to a final concentration of $0.75 \mu \mathrm{M}$ was added. The cells were incubated for $20 \mathrm{~h}$.

Cell staining. After incubation, the cells were stained with fluorescent proteins: $1.5 \mu \mathrm{M}$ EGFPSubB or $1.5 \mu \mathrm{M}$ EGFP (control for nonspecific sorption). The optimal number of cells for staining was $0.3-0.5 \times 10^{6}$ cells per sample. To cells, preliminary precipitated at 200-300 g for $10 \mathrm{~min}$, we added $1.45 \mu \mathrm{M}$ fluorescent protein in $200 \mu \mathrm{l}$ of BSA/PBS solution $\left(0.14 \mathrm{M} \mathrm{NaCl}, 0.03 \mathrm{M} \mathrm{KCl}, 0.01 \mathrm{M} \mathrm{Na}_{2} \mathrm{HPO}_{4}\right.$, $0.002 \mathrm{M} \mathrm{KH}_{2} \mathrm{PO}_{4}, 1 \% \mathrm{BSA}$; pH 7.2) to each sample. Cells were stained for $15 \mathrm{~min}$ at $4{ }^{\circ} \mathrm{C}$. To remove unbound fluorescent proteins, the cells were gently resuspended in BSA/PBS solution (added to the volume of $1 \mathrm{ml}$ ) and again precipitated at 200-300 g for $10 \mathrm{~min}$. The incubation medium was replaced with a similar volume of BSA/PBS. After this, the suspension of the stained cells was transferred to the test tubes for the flow cytometry analysis.

Flow cytometry. The fluorescence intensity of cells was measured by Coulter Epics XL flow cytometer (Beckman Coulter, USA). The results of flow cytometry were normalized to control values of cell autofluorescence, and the output was re-normalized to the value of nonspecific sorption (EGFP stained samples).

Parameters employed for the cytometer software protocol were: small angle forward-scattered light (FS), $90^{\circ}$ side-scattered light (SS) and logarithmic fluorescence on FL1 channel (515-535 nm). The FS parameters were: voltage (Volts) - 500, amplification coefficient (Gain) - 1.0. The SS parameters were: Volts - 500, Gain - 5.0. FL1 parameters: Volts -700 , Gain -10 . Flow rate - medium or low depending on the number of cells in the sample. The above settings were determined experimentally.

Based on the data obtained, the cell distribution by forward- and side-scattered light that allows determining the cell morphology and the fluorescence intensity by the channel FL1 Log were calculated.

Flow cytometry data analysis was carried out using Flowing Software (Cell Imaging Core, Turku Center for Biotechnology, Finland). The number of measurements (events) employed to plot histograms was 10,000 . At the histogram analysis, the value of the ratio of the fluorescence intensity in the experiment to the fluorescence intensity in the control in the range from 0.5 to 2 was considered to be slightly different from 1, i.e. in these cases, the intensity of fluorescence in the experiment differed from the intensity of fluorescence in the control no more than 2-fold.

\section{Results and Discussion}

Studying proHB-EGF expression on the surface of immune cells under standard culture conditions in vitro. At the first stage, we studied the proHBEGF expression on J774, Raji and KG-1 cell lines unexposed to any additional factors. Analysis of cell size and granularity revealed two subpopulations in all studied cell lines: a small granular subpopulation (non-viable cells with damaged cell membrane integrity) and a large less granular subpopulation (viable cells). In further experiments, the proHB-EGF expression on subpopulations of viable cells of J774, Raji and KG-1 lines was studied by measuring the fluorescence of EGFP-SubB ligand.

The results of cytofluorimetric analysis of the cells stained with EGFP-SubB or EGFP (control for nonspecific sorption) are shown in Fig. 1. Autofluorescence of unstained cells was taken as a normal signal. The J774 and Raji cells bound proHB-EGF ligand - EGFP-SubB, while the KG-1 cells did not bind EGFP-SubB (the binding was found to be at the level of nonspecific sorption). Raji cells evidently expressed the largest quantity of proHB-EGF on their surfaces (3-fold increase in fluorescence compared to control for non-specific sorption), and $\mathrm{J} 774$ cells expressed less proHB-EGF (1.5-2 fold increase in fluorescence compared to control for nonspecific sorption). Further studies were carried out on cells of

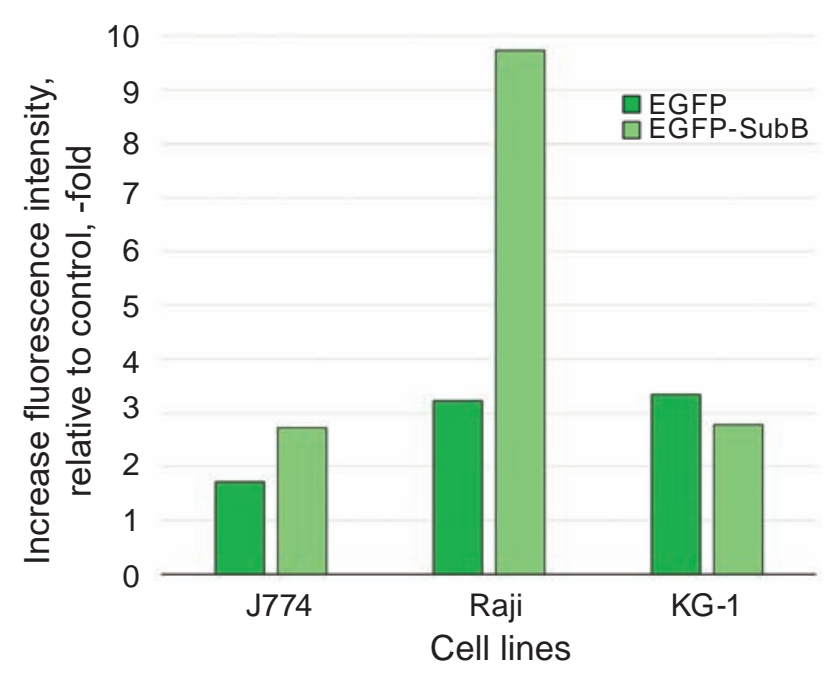

Fig. 1. Fluorescence intensity of Raji, J774, KG-1 cells stained with EGFP-SubB or EGFP, relative to control (unstained cells) 


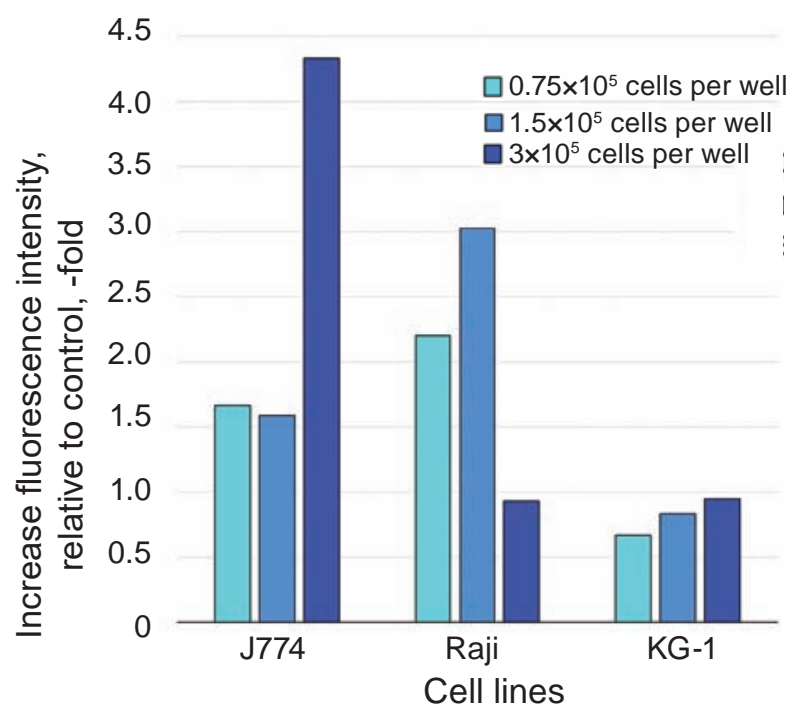

Fig. 2. Fluorescence intensity of Raji, J774 and $K G-1$ cells stained with EGFP-SubB, relative to control (cells stained with EGFP), depending on cell density in plate well

3 lines derived from immune cells, which possessed different initial levels of proHB-EGF expression: high (Raji), low (J774) and almost zero level (KG-1). KG-1 cells were used as a control, and in further experiments, they did not respond to the activating factors by changes in the level of their proHB-EGF expression.

Studying proHB-EGF expression on the cell surface of immune system cells under the influence of activating factors: changes in cell density, changes in FBS concentration, and the presence of LPS, CRM197 or rsHB-EGF. The results obtained showed that J774 cells' ability to interact with proHB-EGF ligand at a high cell density in culture $\left(3 \times 10^{5}\right.$ cells per well) increased 2.5-3-fold compared to the control sample $\left(1.5 \times 10^{5}\right.$ cells per well) (Fig. 2). Raji cells, on the contrary, better bound proHB-EGF ligand at a lower density. An increase in density up to $3 \times 10^{5}$ cells per well resulted in a 3-fold decrease in binding proHB-EGF ligand compared to the control sample.

J774 and Raji cells were found to tend to an increased level of proHB-EGF expression with an increase in the medium FBS concentration. J774 cells exhibited approximately 2-fold higher level of proHB-EGF expression at 20\% FBS than at 2 and 10\% FBS (Fig. 3), while Raji cells exhibited a slight increase in proHB-EGF expression at 10 and 20\% FBS (1.3-fold) compared to 2\% FBS.

The addition of LPS led to an increase in the level of the proHB-EGF expression by J774 cells

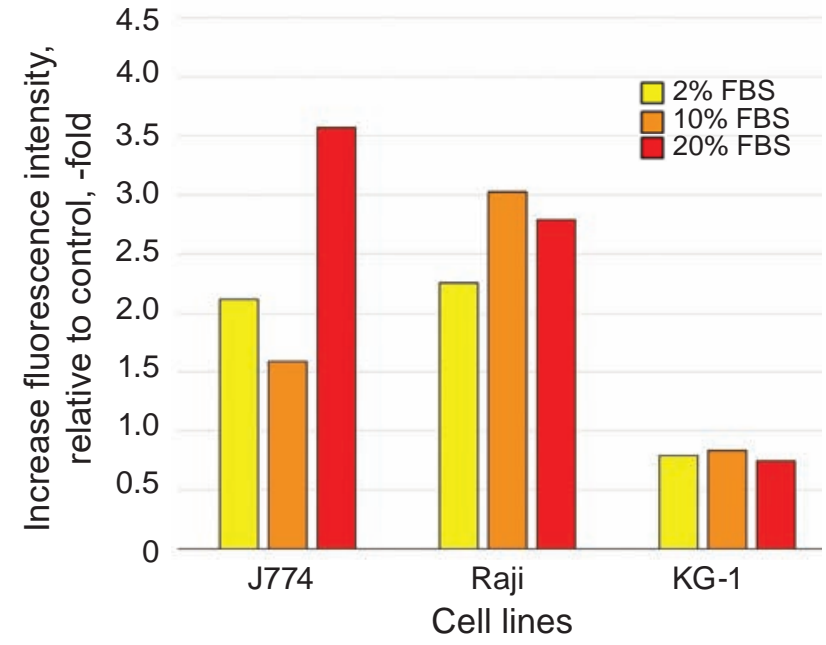

Fig. 3. Fluorescence intensity of Raji, J774 and KG-1 cells stained with EGFP-SubB, relative to control (cells stained with EGFP), depending on FBS concentration in culture medium

(more than 2-fold compared to the control) and a slight decrease in the proHB-EGF expression by Raji cells (Fig. 4).

Culturing $\mathrm{J} 774$ and Raji cells in the presence of rsHB-EGF resulted in opposite effects (Fig. 5): proHB-EGF expression on J774 cells increased 1.3fold, and on Raji cells decreased 1.3-fold. Culturing in the presence of a DT analogue (CRM197) had practically no effect on the proHB-EGF expression

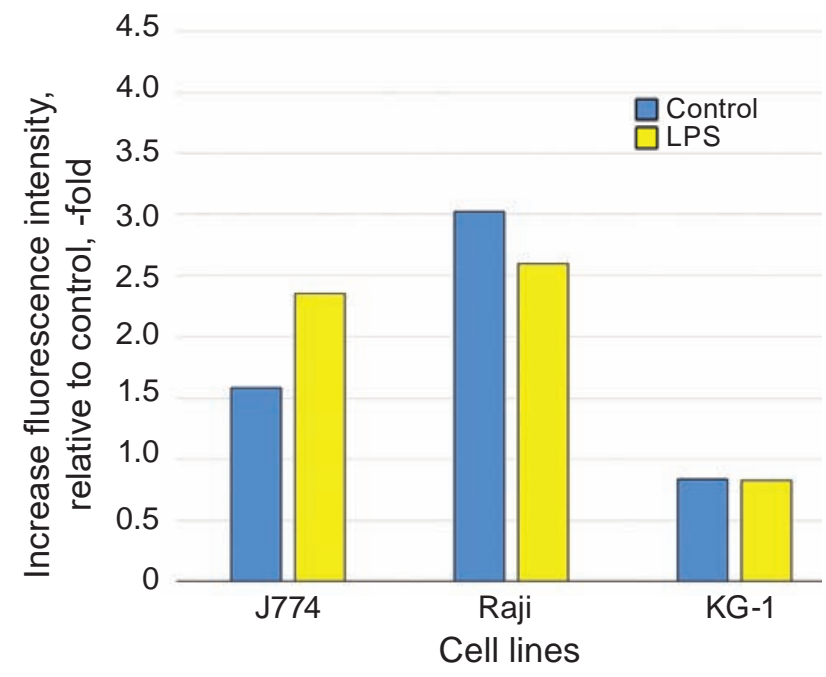

Fig. 4. Fluorescence intensity of Raji, J774 and $K G-1$ cells stained with EGFP-SubB, relative to control (cells stained with EGFP), in the presence of mitogen LPS in culture medium 


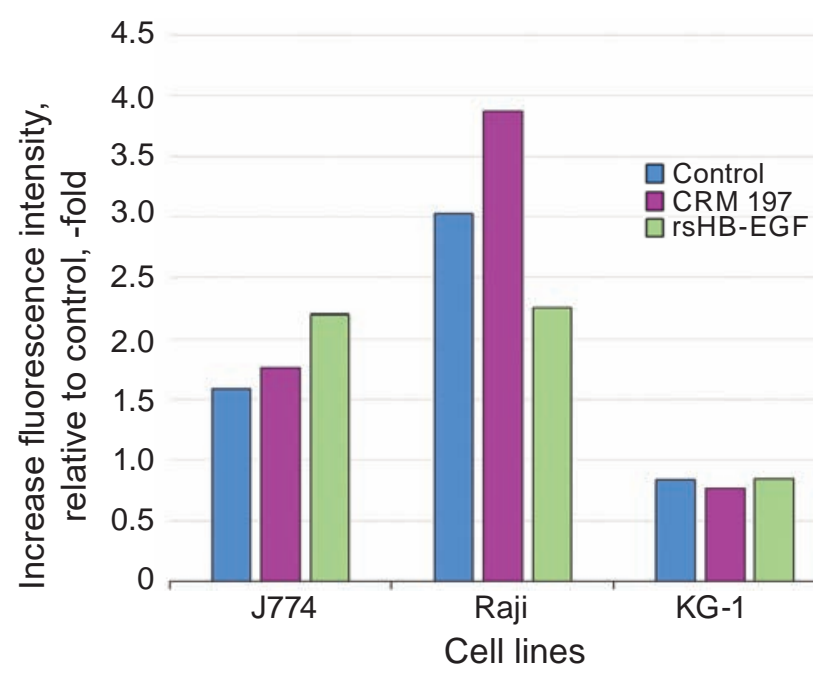

Fig. 5. Fluorescence intensity of Raji, J774 and $K G-1$ cells stained with EGFP-SubB, relative to control (cells stained with EGFP), in the presence of recombinant proteins: nontoxic analogue of diphtheria toxin CRM197 or analogue of soluble form of HB-EGF - rSHB-EGF

by J774 cells, but enhanced the proHB-EGF expression (1.3-fold) by Raji cells.

Data on the changes in proHB-EGF expression on the surface of J774 and Raji cells (KG-1 cells were taken as control) under the influence of various activating factors: increasing cell density in culture, increasing FBS concentration, the presence of LPS, CRM197 or rsHB-EGF in culture medium are summarized in Table.

Interestingly, the nontoxic DT analogue - recombinant protein CRM197 - did not alter expression of proHB-EGF by J774 cells but increased proHB-EGF expression by Raji cells. This is probab- ly due to cell peculiarities across species: human cells (Raji) are susceptible to DT, while mouse cells (J774) are resistant to DT. DT was shown to bind to proHB-EGF on the cell surface of both toxin-susceptible and toxin-resistant organisms that led to internalization of the complex [18]. However, in cells of resistant to DT organisms, subA translocation from endosomes to the cytosol did not occur, probably, due to the effect of DT T-domain on the endosomal $\mathrm{pH}$ [19]. Mouse cells are characterized by lower DT binding activity of proHB-EGF due to differences in the proHB-EGF amino acid sequences across species [20] and proHB-EGF-associated transmembrane protein CD9, which in mice is not able to upregulate DT binding activity of proHB-EGF [21]. These differences are likely to affect signal transmission from proHB-EGF receptor after its binding to CRM197, which increases proHB-EGF expression only on human cells.

Thus, J774 cells derived from mouse macrophages and possessed a low initial level of proHBEGF expression, in most cases responded to activating factors by increasing proHB-EGF expression, while Raji cells derived from human B cells and possessed a high initial level of proHB-EGF expression responded to activating factors mainly by decreasing proHB-EGF expression.

The changes in an amount of proHB-EGF on the cell surface can be realized via two main mechanisms: first, by altering the synthesis of proHB-EGF de novo; second, by changing the intensity of proHBEGF shedding to form a soluble form - sHB-EGF. The formation of sHB-EGF depends on many factors and negatively regulated, i.e. is inversely proportional to the amount of sHB-EGF in a medium.

Changes in proHB-EGF expression on the J774 and Raji cell surface in the presence of activating factors

\begin{tabular}{l|c|c}
\hline \multicolumn{1}{c|}{ Cell line } & J774 & Raji \\
\hline Origin & Mouse macrophages & Human B cells \\
Initial level of proHB-EGF & low & high \\
Increase in cell density & + & - \\
Increase in FBS concentration in medium & + & - - \\
LPS & + & -- \\
CRM197 & & + \\
rsHB-EGF & + & - \\
\hline
\end{tabular}

Notes: + increase in proHB-EGF expression; -|- slight increase in proHB-EGF expression; - decrease in proHB-EGF expression; -- slight decrease in proHB-EGF expression; Empty cell - proHB-EGF expression remains unchanged 
Different types of cells are supposed to employ different mechanisms for changing proHB-EGF expression under the influence of activating factors.

The studied J774 and Raji cells derive from different immune system cell types: macrophages and B cells, respectively, which significantly differ in their functional purpose. Macrophages migrate to inflammation area, scavenge and digest pathogens; they are involved in the wound healing process, secreting a large amount of growth factors. Due to intensive sHB-EGF shedding by J774 cells, the level of membrane proHB-EGF expression was low. The main tasks of $B$ cells are recognition of antigen of a pathogenic agent, differentiation into plasma cells, which synthesize specific antibodies. Raji cells are likely to secrete a small amount of sHB-EGF into the medium and therefore, express a large amount of proHB-EGF on their surface.

The functional differences between macrophages and $\mathrm{B}$ cells underlie different responses of these cells to activating factors. When macrophages, which secrete a significant amount of sHB-EGF in the inflammatory focus, receive signals of an increase in their density in the inflammation area, the presence of other mitogen factors and a sufficient amount of sHB-EGF in the medium, they reduce sHB-EGF shedding that lead to an increase in the amount of detectable proHB-EGF on the cell surface. This process was observed at the increase in cell density and FBS concentration, as well as under the effects of LPS and rsHB-EGF on J774 cells. B cells, possessing a large amount of proHB-EGF on their surface, are always ready to respond to mitogen agents from other cells by producing their own sHB-EGF. This process is thought to be important for triggering proliferation of some B cell clones that recognize an antigen and interact with $\mathrm{T}$ helper cells and to support the formation of a large number of antibody-producing cells and the formation of a strong humoral immune response. Thus, increasing sHB-EGF expression in response to such activating factors as an increase in cell density, the presence of LPS and rsHB-EGF resulted in a decrease in the amount of proHB-EGF on Raji cells.

A slight increase in the amount of proHB-EGF on the Raji cells surface at high FBS concentrations is thought to be caused by activated cell metabolism owing to growth factors present in FBS and an increase in proHB-EGF synthesis de novo.

The immune system functions as a well-organized organism owing to a large number of receptors on the cell surface of different immune cell subpopulations, that are involved in constant signal transmission realized through receptors of neighboring cells, binding of cytokines, hormones, neuropeptides, growth factors, etc. Recognition of these signals leads to metabolic changes in cell, synthesis or removal of its own receptors. The results obtained showed that proHB-EGF receptor plays an important role in the regulation of the immune system cell activity (at least macrophage-like and B cells), providing (along with other factors) various responses to activating factors and supporting immune system cells functioning to form full protection of the organism against pathogenic agents.

\section{ЗМІНИ В ЕКСПРЕСІÏ рroHВ-ЕGF ПІД ЧАС ФУНКЦІОНАЛЬНОЇ АКТИВАЦІї КЛІТИН ІМУННОї СИСТЕМИ}

\author{
T. О. Чудіна ${ }^{1,2}$, А. Ю. Лабинцев ${ }^{1}$, \\ С. І. Романюк 1 Д. В. Колибо, \\ С. В. Комісаренко ${ }^{1}$
${ }^{1}$ Інститут біохімії ім. О. В. Палладіна НАН України, Київ; Київський національний університет імені Тараса Шевченка, Україна; \\ ${ }^{2}$ ННЦ «Інститут біології та медицини», \\ e-mail: kolibo@biochem.kiev.ua
}

Досліджено рівень експресії proHB-EGF на клітинах ліній J774, Raji, KG-1, що походять 3 різних типів клітин імунної системи людини та миші, за стандартних умов культивування in vitro та під час функціональної активації цих клітин. Виявлено зміни експресії proHBEGF на поверхні клітин залежно від щільності клітинної популяції, вмісту фетальної сироватки бика у культуральному середовищі, під впливом мітогенного чинника - ліпополісахариду бактеріального походження, а також неактивної повнорозмірної форми дифтерійного токсину (CRM197) i рекомбінантного аналога розчинної форми HB-EGF - rsHB-EGF. Одержані результати є важливими для розуміння функціональної ролі рецептора proHBEGF на поверхні макрофагоподібних клітин i В-лімфоцитів та свідчать про залучення цього рецептора до регуляції імунних процесів в організмі.

К л ю ч о в і с ло в а: proHB-EGF, експресія, клітинні лінії, макрофаги, В-лімфоцити, 
ліпополісахарид, рекомбінантні протеїни, sHBEGF, неактивний дифтерійний токсин CRM197.

\section{ИЗМЕНЕНИЯ \\ В ЭКСПРЕССИИ рroНВ-ЕGF ПРИ ФУНКЦИОНАЛЬНОЙ АКТИВАЦИИ КЛЕТОК ИММУННОЙ СИСТЕМЫ}

\author{
T. А. Чудина ${ }^{1,2}$, А. Ю. Лабыниев ${ }^{1}$, \\ С. И. Романюк', Д. В. Колибо ${ }^{1,2}$, \\ С. В. Комисаренко ${ }^{1}$
}

${ }^{1}$ Институт биохимии им. А. В. Палладина НАН Украины, Киев;

${ }^{2}$ УНЦ «Институт биологии и медицины»,

Киевский национальный университет имени Тараса Шевченко, Украина; e-mail: kolibo@biochem.kiev.ua

Исследован уровень экспрессии proHBEGF на клетках линий J774, Raji, KG-1, происходящих от различных типов клеток иммунной системы человека и мыши, при стандартных условиях культивирования in vitro и при функциональной активации этих клеток. Выявлены изменения экспрессии proHB-EGF на поверхности клеток в зависимости от плотности клеточной популяции, содержания фетальной сыворотки быка в культуральной среде, под влиянием митогенного фактора - липополисахарида бактериального происхождения, а также неактивной полноразмерной формы дифтерийного токсина (CRM197) и рекомбинантного аналога растворимой формы HB-EGF - rsHB-EGF. Полученные результаты важны для понимания функциональной роли рецептора proHB-EGF на поверхности макрофагоподобных клеток и В-лимфоцитов, и свидетельствуют об участии этого рецептора в регуляции иммунных процессов в организме.

Ключевы е сллов а: proHB-EGF, экспрессия, клеточные линии, макрофаги, В-лимфоциты, липополисахарид, рекомбинантные протеины, sHB-EGF, неактивный дифтерийный токсин CRM197.

\section{References}

1. Higashiyama S, Abraham JA, Miller J, Fiddes JC, Klagsbrun M. A heparin-binding growth factor secreted by macrophage-like cells that is related to EGF. Science. 1991; 251(4996): 936-939.

2. Yan Y, Shirakabe K, Werb Z. The metalloprotease Kuzbanian (ADAM10) mediates the transactivation of EGF receptor by $G$ protein-coupled receptors. J Cell Biol. 2002; 158(2): 221-226.

3. Jones JT, Akita RW, Sliwkowski MX. Binding specificities and affinities of EGF domains for ErbB receptors. FEBS Lett. 1999; 447(2-3): 227231.

4. Auf G, Jabouille A, Delugin M, Guérit S, Pineau R, North S, Platonova N, Maitre M, Favereaux A, Vajkoczy P, Seno M, Bikfalvi A, Minchenko D, Minchenko O. High epiregulin expression in human U87 glioma cells relies on IRE1 $\alpha$ and promotes autocrine growth through EGF receptor. BMC Cancer. 2013; 1(1): 597.

5. Besner G, Higashiyama S, Klagsbrun M. Isolation and characterization of a macrophagederived heparin-binding growth factor. Cell Regul. 1990; 1(11): 811-819.

6. Nakamura K, Iwamoto R, Mekada E. Membrane-anchored heparin-binding EGF-like growth factor (HB-EGF) and diphtheria toxin receptor-associated protein (DRAP27)/CD9 form a complex with integrin alpha 3 beta 1 at cell-cell contact sites. J Cell Biol. 1995; 129(6): 1691-1705.

7. Raab G, Klagsbrun M. Heparin-binding EGFlike growth factor. Biochim Biophys Acta. 1997; 1333(3): F179-F199.

8. Naglich JG, Metherall JE, Russell DW, Eidels L. Expression cloning of a diphtheria toxin receptor: identity with a heparin-binding EGFlike growth factor precursor. Cell. 1992; 69(6): 1051-1061.

9. Kolibo DV, Romanyuk SI, Radavskiy YuL, Komisarenko SV. Influence of diphtheria toxin on the vitality of phagocytes and B-lymphocytes of the animals sensitive and insensitive to it. $U k r$ Biokhim Zhurn. 2002; 74(2): 30-36. 
10. Van Ness BG, Howard JB, Bodley JW. ADPribosylation of elongation factor 2 by diphtheria toxin. Isolation and properties of the novel ribosyl-amino acid and its hydrolysis products. J Biol Chem. 1980; 255(22): 10717-10720.

11. Collier RJ. Diphtheria toxin: mode of action and structure. Bacteriol Rev. 1975; 39(1): 54-85.

12. Vaughan TJ, Pascall JC, Brown KD. Tissue distribution of mRNA for heparin-binding epidermal growth factor. Biochem J. 1992; 287(Pt 3): 681-684.

13. Blotnick S, Peoples GE, Freeman MR, Eberlein TJ, Klagsbrun M. T lymphocytes synthesize and export heparin-binding epidermal growth factor-like growth factor and basic fibroblast growth factor, mitogens for vascular cells and fibroblasts: differential production and release by CD4+ and CD8+ T cells. Proc Natl Acad Sci USA. 1994; 91(8): 2890-2894.

14. De Vos J, Couderc G, Tarte K, Jourdan M, Requirand G, Delteil MC, Rossi JF, Mechti N, Klein B. Identifying intercellular signaling genes expressed in malignant plasma cells by using complementary DNA arrays. Blood. 2001; 98(3): 771-780.

15. Labyntsev AJ, Korotkevych NV, Manoilov KJ, Kaberniuk AA, Kolybo DV, Komisarenko SV. Recombinant fluorescent models for studying the diphtheria toxin. Russ J Bioorg Chem. 2014; 40(4): 401-409.

16. Korotkevich NV, Kolibo DV, Labyntsev AJ, Romaniuk SI, Komisarenko SV. Obtaining of recombinant human heparin binding EGF-like growth factor and perspectives of its application in biotechnology. Biotechnology. 2010; 3(4):4454. (In Ukrainian).

17. Kaberniuk AA, Labyntsev AJ, Kolybo DV, Oliinyk OS, Redchuk TA, Korotkevich NV, Horchev VF, Karakhim SO, Komisarenko SV. Fluorescent derivatives of diphtheria toxin subunit B and their interaction with Vero cells. Ukr Biokhim Zhurn. 2009; 81(1): 67-77. (In Ukrainian).

18. Labyntsev AJ, Korotkevich NV, Kaberniuk AA, Romaniuk SI, Kolybo DV, Komisarenko SV. Interaction of diphtheria toxin B subunit with sensitive and insensitive mammalian cells. Ukr Biokhim Zhurn. 2010; 82(6): 65-75. (In Ukrainian).

19. Labyntsev AJ, Korotkevych NV, Kolybo DV, Komisarenko SV. Effect of diphtheria toxin T-domain on endosomal pH. Ukr Biochem $J$. 2015; 87(4): 13-23.

20. Abraham JA, Damm D, Bajardi A, Miller J, Klagsbrun M, Ezekowitz RA. Heparin-binding EGF-like growth factor: characterization of rat and mouse cDNA clones, protein domain conservation across species, and transcript expression in tissues. Biochem Biophys Res Commun. 1993; 190(1): 125-133.

21. Hasuwa H, Shishido Y, Yamazaki A, Kobayashi T, Yu X, Mekada E. CD9 amino acids critical for upregulation of diphtheria toxin binding. Biochem Biophys Res Commun. 2001; 289(4): 782-790. 